\title{
Mechanisms and sources of investment development of agriculture in resource-deficient regions: russian and foreign experience
}

\author{
Ekaterina Sorokina* \\ Ural State University of Economics, Yekaterinburg, Russia
}

\begin{abstract}
In the article, the author presents an analytical review of the mechanisms and sources of investment development of agriculture in resource-deficient regions (Russian and foreign experience). Mechanisms for the development of agriculture in the region are proposed (provision of tax incentives/ holidays for agricultural producers; construction of housing for employees working in the field of agriculture; drawing up a map of priority projects for which state support is needed; provision of fuel and lubricants to entrepreneurs on a free basis during the sowing period; formation of standard models of strategic documents for the development of agriculture in resource-deficient regions; etc.). The author proposes to introduce a "failure-target" approach to the formation, financing and implementation of projects in the field of agriculture in resource-deficient regions. The proposals presented by the author will improve the quality of strategic planning of the territory; expand the process of digitalization in the field of agriculture, allow more efficient spending of budget funds, improve the quality of project management approach.
\end{abstract}

\section{Introduction}

Today, in the period of sanctions policy, the presence of approved tasks and targets/parameters in regional and federal state programs for the development of the agroindustrial complex, as well as the implementation of measures to reduce the resource shortage of regions, the development of mechanisms and the search for sources of investment development of agriculture in resource-deficient regions is becoming highly relevant.

The significance of the study is complemented by the consequences of the global situation, as well as the situation with COVID-19: "The level of hunger has increased over the past five years. Nearly 690 million people go to bed hungry every night. The growth of hungry people is predicted if measures are not taken"[1]. At the same time, in this source, the importance of the research topic is emphasized by the following confirmed fact: "Food production and agriculture provide the livelihood of more people in the world than any other sector"[1].

\footnotetext{
*Corresponding author: sorokinaea@gmail.com.
} 
The interpretation of the concept of "investment attractiveness" is revealed in the works of the following Russian and foreign scientists: G. Alexander, J. Bailey, I. A. Blank, E. Bodi, L. S. Valinurov, Yu. P. Volkodav, A. R. Zyumalin, P. A. Kohno, A. Markus, V. A. Mashkin, A. O. Mozgoev, E. A. Oleynikov, M. V. Pirogov, I. I. Roizman, E. A. Ustimenko, S. A. Filin, R. S. Higgins, W. Sharp, etc.

The mechanisms and factors of ensuring the investment attractiveness of territories are disclosed in the works of: M. A. Aseyev, L. K. Egorov, E. Yu. Loktev, B. A.-Kh. Muzykaev, R. A. Mustafin, M. V. Tereshina, I. A. Filippov, T. I. Yakimenko, etc.

The instruments of state regulation of the regional economy are indicated in the works of the following researchers: D. M. Amunts, V. D. Andrianov, I. V. Baskakov, E. N. Veduta, P. V. Vorobyov, G. S. Gazimagomedov, S. M. Kadochnikov, M. V. Kalugin, L. I. Krasovskaya, S. G. Pyankova, R. Yu. Skokov, G. I. Yuryevna, etc.

Management and development of resource-deficient regions is reflected in the works of O. N. Ananyeva, M. A. Aseeva, E. N. Akhmetova, A.V. Babanov, L. K. Egorova, O. T. Ergunova, A.V. Lebedev, T. Li, L. Ma, N. N. Petrova, S. E. Polyakov, A. Yu. Prokhorov, and others.

In earlier studies, the author revealed the conceptual framework for the topic under study ("investment attractiveness", "investment attractiveness of the region", "investment climate", "economic resources of the region", "resource-deficient region"), proposed a scheme for forming the investment attractiveness of a resource-deficient region [2], proposed sources for increasing the investment attractiveness of a resource-deficient region, presented elements of the investment development strategy of a resource-deficient region [3], the methodological foundations of the formation of the investment attractiveness of the region in the form of a schematized logical approach are proposed [4].

In order to continue the research, the author studied the mechanisms and sources of investment development of agriculture in the regions proposed by Russian and foreign scientists, and also proposed the author's approach within the framework of the research topic.

\section{Materials and methods}

In recent decades, reports at the world and Russian levels have shown an alarming trend associated with a decrease in public and private investment in agricultural development, in particular, this problem was voiced at the following events: World Food Summit, 1996; Antholt, 1994; Evenson, McKinsey, 1991; Pray and Evenson, 1991; Pardey Roseboom, Craig, 1992 [5].

At the same time, the researchers note that the countries that have invested and continue to invest the most in agriculture - both public and private - have the lowest level of "malnutrition" [6].

In addition, the analytical materials of foreign countries focus on the following dependence: "stimulating investment and supporting innovation in the agriculture sector contributes to inclusive growth and helps partner countries better "feed" their populations, while protecting their natural resources" [7].

The International Institute for Sustainable Development has developed a practical guide to investing in agriculture and food systems for parliamentarians and advisers. The conclusion of this study is that "sustainable" investment across the agricultural value chain can play an important role in global development through 2030, supporting countries to mitigate climate change and environmental degradation, as well as to address rural poverty and inequality [8].

At the same time, the researchers confirmed that faster growth in agricultural production is associated with increased investment in research and development. As a result, 
investment in research has become an important factor in improving the productivity of the farm, and, accordingly, the growth of real incomes[9].

As a result of the research of Russian and foreign scientists, the author identified the mechanisms and sources of investment development of agriculture in the regions (including resource-deficient ones), in particular:

1. Mechanisms:

- Inclusion human capital formation and environmental degradation in investments in agriculture (Zepeda L.)[10];

- formation of a monitoring system that allows identifying a specific economic entity for investing funds based on the formation of investment passports of potential recipients (Manzhosova I. B., Rodina E. V., Dolgopolova A. F., Shepet I. P., Ryabov V. N) [11]

- allocation of a certain part of China's land for agriculture (especially grain cultivation)[12];

- development of rural development programs by the state and the regions, based on the needs of their territories and taking into account some of the common priorities of the European Union. At the same time, $30 \%$ of the funding for each program should be allocated to measures related to the environment and climate change[13];

- support for young farmers, making payments to areas facing natural or other specific restrictions, and implementing agroecological and climate measures[14];

- development of the symbiosis of science and technology in terms of changing the appearance of agriculture[15];

- formation of a methodology for assessing the effectiveness of the functioning of each of the subsystems of state regulation of the agricultural sector of the economy, including the subsystem of state support for agricultural producers (Sharapova N. V.) [16];

- drawing up a methodology for assessing the financial and investment potential, including the formation of a multi-channel financing system (Tolstolesova L. A.)[17];

- creation of a strategic plan for innovative development, which involves defining the stages and corresponding tasks of innovative development of agriculture (medium and long-term perspective) (Zolotareva E. L., Plakhin E. S.)[18];

- drawing up a methodology for a phased multi-criteria assessment of the priority of implementing alternative innovation and investment projects according to a set of parameters, the difference of which is to expand the boundaries of its applicability not only for individual enterprises, but also for all participants of the innovation and investment cluster (Orekhova M. S.)[19];

- implementation of the methodology for the formation of an organizational and economic mechanism for investing in agricultural production as a system of economic forms and methods of organizing investment, forecasting and planning, controlling, and capital movement (Semina L. A.) [20].

\section{Sources:}

- increase of public and private investments in agriculture, development of public-private partnership (M. Wales) [21];

- financing from development institutions: European Agricultural Fund for Rural Development (Fuglie K., Wang S. L, Njuki E.)[22]; Investment Fund of the Russian Federation (Shkarupa E. A.) [23]; stock market (Tyu L. V.)[24];

- formation of a mechanism for attracting investments in the fixed capital of the agricultural sector of the Russian economy at the present stage (Zakshevsky V. G., Zhdanov D. S.) [18]. 


\section{Results and discussion}

Summarizing the proposals of scientists and researchers, the author suggests using the following mechanisms for the development of agriculture in resource-deficient regions, in addition to the existing ones:

- tax benefits/ holidays for agricultural producers;

- construction of housing for employees working in the field of agriculture, with an experience of more than 10 years;

- provision of fuel and lubricants to entrepreneurs free of charge during the sowing period;

- introduction of the author's "failure-target" approach in the formation, financing and implementation of projects in the field of agriculture in resource-deficient regions;

- drawing up a map of priority projects for which state support is needed;

- maintaining an automated database of projects in resource-deficient regions;

- study of the experience of best practices in the field of agriculture in resource-deficient regions;

- holding an annual competition for the effective development of agriculture in the regions;

- formation of standard models of strategic documents for the development of agriculture in resource-deficient regions;

- search for investors to implement projects for the development of agriculture in resourcedeficient regions;

- mechanization of all sowing and harvesting processes, introduction of digital technologies;

- state support for start-up entrepreneurs engaged in the development of agriculture;

- formation of a consortium of science, business and government for the development of agriculture in resource-deficient regions;

- advanced training of personnel working in the field of agriculture;

- providing loans to entrepreneurs at a reduced rate for the development of agricultural activities in resource-deficient regions;

- the introduction of grants at the level of state authorities aimed at stimulating the development of agriculture in the region;

- drawing up a state plan for 5 years for the development of agriculture in the regions of the country;

- formation of inter-municipal / interregional cooperation in the direction of stimulating agriculture in the region;

- introduction of a distribution system for university graduates who have graduated from specialized institutes for the development of agriculture;

- increase in target places for free training in the specialty " agriculture»;

- introduction of regular monitoring of investment development of agriculture in resourcedeficient regions;

- attracting shift workers from nearby territories for centralized development of agriculture;

- creation of incubators and technology parks in the field of activity " agriculture»;

- creation of special regional economic zones where effective and productive activities in the field of "agriculture"are carried out.

As sources of investment development of agriculture in resource-deficient regions, the author suggests introducing regional investment funds for agricultural development. It is proposed to consider the financing of agriculture through the "project approach". 


\section{Conclusion}

The mechanisms and sources of investment development of agriculture in resourcedeficient regions presented by the author will provide up-to-date information about the potential recipient of investments of the agro-industrial complex in the region; improve the quality of strategic planning of the territory; expand the process of digitalization in the field of agriculture, allow more efficient spending of budget funds, and improve the quality of project approach management. The introduction of the author's "failure-target" approach to the formation and implementation of projects in the field of agriculture in resourcedeficient regions will allow us to identify opportunities to improve the efficiency of activities in the field of agriculture, to set and achieve goals for the development of this industry.

\section{References}

1. Food and Agriculture / International Institute for Sustainable Development. https://www.iisd.org/topics/food-and-agriculture.

2. S.G. Pyankova, E.A. Sorokina, Investment attractiveness of a resource-deficient region: terminology and assessment methods, I International Volga Region Conference on Economics, Humanities and Sports FICEHS 2019 (WoS), Kazan, Naberezhnye Chelny, Russia.

3. S.G. Pyankova, E.A.Sorokina, Increasing investment attractiveness of the resourcedeficiency region, International scientific-practical conference "Ecological-socioeconomic systems: models of competition and cooperation" (WoS). October 24, 2019. Kurgan, Russia. https://www.atlantis-press.com/proceedings/eses-19/125932047.

4. S.G. Pyankova, E. A. Sorokina, Methodological bases of formation of investment attractiveness of the resource-deficient region: russian and international aspects, II International Scientific and Practical Conference on the Digital Economy (ISCDE 2020). https://www.atlantis-press.com/proceedings/iscde-20/125947817.

5. L. Zepeda, Agricultural Investment, Production Capacity and Productivity, Agriculture and Economic. http://www.fao.org/3/x9447e03.htm.

6. M. Wales, Investment in Agriculture and Rural Development. FAO Policy Learning Program. Investitsionnyy tsentr, FAO, Rim, Italiya. http://www.fao.org/docs/up/easypol/501/investment_agric_rural_dev_088en.pdf.

7. Investing in sustainable agriculture and food systems, European Commission. https://ec.europa.eu/international-partnerships/topics/investing-sustainable-agricultureand-food-systems_en.

8. Europe Launch. The role of responsible investments in agriculture for the transition towards more sustainable food systems / WEBINAR / December 7, 2020 12:00 pm 1:30 pm CET. International Institute for Sustainable Development. https://www.iisd.org/events/europe-launch-role-responsible-investments-agriculturetransition-towards-more-sustainable.

9. Investment in Agricultural Research: Some Economic Principles Grant M. Scobie Senior Agricultural Economist Ruakura Agricultural Research Center Hamilton, New Zealand Working Paper Prepared for CIMMYT, Mexico, August 1984.

10. L. Zepeda, Agricultural Investment, Production Capacity and Productivity, Agriculture and Economic. http://www.fao.org/3/x9447e03.htm. 
11. I.B. Manzhosova, E.V. Rodina, A.F. Dolgopolova, I.P. Shepet, V.N. Ryabov, Journal of Internet Banking and Commerce 21(6), (2016).

12. China's 2014 State Policy on Rural Development and the Agriculture Industry: Investment Implications / China Briefing. May 27, 2014. https://www.chinabriefing.com/news/chinas-state-policy-rural-development-agriculture-industry/.

13. Project summary. The Challenge / Investing in Renewable Energies for Agriculture / AgroRES. Interreg Europe. https://www.interregeurope.eu/agrores/.

14. European Agricultural Fund for Rural Development. https://www.europe-enfrance.gouv.fr/en/european-funds/european-agricultural-fund-rural-developmentEAFRD.

15. A UK Strategy for Agricultural Technologies / Industrial Strategy: government and industry in partnership. HM Government. July 2013.52 p.

16. N.V. Sharapova, Organizational and economic mechanism for supporting agricultural producers in the system of state regulation of the industry. Diss. for a job. learned. step. Dan. / Specialty 08.00.05. Yekaterinburg: FGBOU VO "USUE", 286 p. (2019)

17. L.A. Tolstolesova, Financial and investment potential of resource regions: formation and implementation strategy / Author. diss. for the degree of Doctor of Economics St. Petersburg 36 p. (2012).

18. E. L. Zolotareva, E.S. Plakhin, Bulletin of the Kursk State Agricultural Academy, 5 (2015)

19. M.S. Orekhova, Ways to improve the efficiency of innovative and investment activities in plant growing in the Krasnodar Territory / Diss. for the degree of candidate of economic sciences / Krasnodar, 205 p. (2018).

20. L.A. Semina, Development of investment and innovation activities in agriculture (theory, methodology, practice). Diss. for a job. learned. step. Dan. Moscow: State Scientific Institution "All-Russian Scientific Research Institute of Agricultural Economics RAAS", 327 p. (2012)

21. M. Wales, Investment in Agriculture and Rural Development. FAO Policy Learning Program. Investitsionnyy tsentr, FAO, Rim, Italiya. http://www.fao.org/docs/up/easypol/501/investment_agric_rural_dev_088en.pdf.

22. K. Fuglie, S. L. Wang, E. Njuki, Agricultural Research and Productivity / Economic Research Service U.S. Department of agriculture. January 13, 2020. https://www.ers.usda.gov/topics/farm-economy/agricultural-research-andproductivity/.

23. E.A. Shkarupa, Bulletin of Volgograd University 3(2), 107 (2011)

24. L.V. Chu, Development of Investment Activities in the Agriculture of the Region. Author. Diss. for the degree of Doctor of Economics / Novosibirsk, 50 p. (2006). http://economy-lib.com/disser/189648/a\#?page $=50$. 